\title{
PENGEMBANGAN BUKU AJAR BERORIENTASI PADA NILAI-NILAI ISLAMI DENGAN MENGGUNAKAN MODEL PBL UNTUK MENINGKATKAN KEMAMPUAN MENGANALISIS PUISI SISWA KELAS V
}

\author{
Samiyah $^{1}$, Bambang Yulianto ${ }^{2}$, Wahyu Sukartiningsih ${ }^{3}$ \\ ${ }^{1}$ Mahasiswa Program Pascasarjana, Prodi Pendidikan Dasar, Universitas Negeri Surabaya, \\ ${ }^{2 \& 3}$ Dosen Pascasarjana, Prodi Pendidikan Dasar, Universitas Negeri Surabaya \\ e-mail: samiyahaffan@gmail.com ${ }^{1}, \underline{\text { bambangyulianto@ unesa.ac.id }}$, ${\text { wahyusukartiningsih@unesa.ac.id }{ }^{3}}^{3}$
}

\section{Received： Juli 2019}

Reviewed : Agustus 2019

Accepted : September 2019

Published : September 2019

\section{ABSTRACT}

The purpose in this research is to describe the quality of book oriented on islamic values by using PBL model to increase the ability to analyse poem at grade $V$ students. Detaily, the purpose of the research is explained into three that is: (1) To describe the validity of student book oriented on islamic value by using PBL model to increase the ability to analyse poem at grade $V$ student. (2) To describe the simplicity of using student book oriented on islamic values by using PBL model to increase the ability to analyse poem at grade $V$ student. (3) To describe the effectiveness of the using student book oriented on islamic values by using PBL model to increase the ability to analyse poem at grade $V$ students. This kind of research is research and development $(R \& D)$ which produce the product of student book oriented on islamic values by using PBL model to increase the ability to analyse poem at grade $V$ students. The design of this research used pretes and postest control group desaign instrument which iis used in this research that is observation sheet, test sheet, guestionaire sheet and validation sheet.It is proved by student's ability as a user showed the very high activity with percentage $87 \%$. Especially in understanding the problem and making evaluation.

Keywords: Text Book, Islamic Values, PBL Model, The Ability to Analyse Poem.

\section{ABSTRAK}

Tujuan dalam penelitian ini adalah mendeskripsikan kelayakan buku ajar berorientasi pada nilai-nilai islami dengan menggunakan model PBL untuk meningkatkan kemampuan menganalisis puisi siswa kelas V. Secara terperinci tujuan penelitian tersebut dijabarkan menjadi tiga, yakni: (1) Mendeskripsikan validitas buku ajar berorientasi pada nilai-nilai islami dengan menggunakan model $P B L$ untuk meningkatkan kemampuan menganalisis puisi siswa kelas $V$, (2) Mendeskripsikan kepraktisan penggunaan buku ajar berorientasi pada nilai-nilai islami dengan menggunakan model PBL untuk meningkatkan kemampuan menganalisis puisi siswa kelas V. (3) Mendeskripsikan keefektifan dari penggunaan buku ajar berorientasi pada nilai-nilai islami dengan menggunakan model PBL untuk meningkatkan kemampuan menganalisis puisi siswa kelas V. Jenis penelitian ini merupakan penelitian dan pengembangan atau $R \& D$ (Research and Development) yang menghasilkan produk buku ajar dengan menggunakan model PBL. Desain penelitian ini menggunakan Pretest-postest control group desain Hasil penelitian ini menunjukkan bahwa buku ajar denhan model PBL layak digunakan dalam pembelajaran. Hasil validasi buku ajar dengan model PBL adalah layak diterapkan dalam pembelajaran dengan sedikit revisi dengan persentase sebesar 96,3\%. Kepraktisan buku ajar dengan menggunakan model PBL dalam pembelajaran menunjukkan hasil yang yang sangat tinggi. Hal tersebut dibuktikan dengan aktivitas siswa sebagai pengguna menunjukkan keaktifan yang sangat tinggi dengan persentase $87 \%$, terutama dalam hal memahami masalah dan melakukan evaluasi. 
Kata Kunci: Buku ajar, Nilai-Nilai Islami, Model PBL, Kemampuan Menganalisis Puisi.

\section{PENDAHULUAN}

Di zaman globalisasi sekarang ini perkembangan ilmu pengetahuan dan teknologi semakin cepat dan mengalami perubahan secara terus menerus sebagai akumulasi respon terhadap permasalahan-permasalahan yang terjadi selama ini. Pengaruh perubahan global memicu perkembangan ilmu pengetahuan, teknologi, seni, dan budaya. Perkembangan tersebut diharapkan dapat diikuti oleh perkembangan mutu pendidikan dan pengajaran yang menuntut perbaikan sistem pendidikan nasional termasuk pengembangan pembelajaran yang berorientasi pada nilai-nilai islami.

Hal ini seharusnya pendidikan jadi alat transformasi nilai-nilai luhur peradaban, tidak hanya menjadi alat mekanik melahirkan anak didik yang pintar dan menguasai buku ajar, melainkan pendidikan yang dapat menanamkan nilai-nilai islami. Selama ini, pendidikan hanya berorientasi pada angka atau nilai semata. Pendidikan yang selama ini dianggap gagal dalam membentuk nilai-nilai islami pada seorang siswa.

Di zaman globalisasi sekarang ini pendidikan menghadapi banyak tantangan di tengah arus informasi bebas sebagai dampak globalisasi, arus informasi tidak terbatas dan tidak terbendung lagi. Salah satu akibatnya adalah budaya yang negatif mudah terserap tanpa filter yang cukup kuat, oleh sebab itu perlu adanya perhatian, khususnya di bidang pendidikan. Upaya pengembangan pembelajaran yang lebih pada nilai-nilai islami yang harus dilakukan supaya mengenai pengembangan manusia seutuhnya.

Dalam Undang-undang Nomor 20 Tahun 2003 tentang sistem pendidikan Nasional pada pasal 3 disebutkan bahwa pendidikan Nasional berfungsi untuk mengembangkan kemampuan dan membentuk watak serta peradaban bangsa yang bermartabat dalam rangka mencerdaskan kehidupan bangsa, bertujuan untuk berkembangnya negara yang demokratis serta bertanggung jawab. Untuk mencapai tujuan itu, sekolah dasar sebagai sebuah lembaga formal dalam memberikan layanan pendidikan berperan mendorong potensi-potensi peserta didik agar menjadi manusia yang beriman dan bertakwa kepada Tuhan Yang Maha Esa, berakhlak mulia, sehat, berilmu, cakap, kreatif, mandiri, dan menjadi warga tumbuh kembang anak, termasuk meningkatkan keterampilan berbahasa.

Pengungkapan di atas menekankan bahwa sekolah mempunyai peran penting dalam membina dan mengembangkan kepribadian. Peserta didik mempunyai sikap, dan prilaku yang berlandaskan pada nilai-nilai yang berlaku.

Sepanjang zaman puisi selalu mengalami perubahan dan perkembangan. Hal ini mengingat hakikatnya sebagai' 'karya seni dan karya sastra yang selalu terjadi ketegangan antara konvensi dan pembaharuan inovasi", (Teeuw, 1983:411). Menurut Samuel Taylor Coleridge (dalam Pradopo, 2010:16), puisi merupakan kata-kata terindah dalam susunan terindah. Penyair memilih katakata yang tepatnya dan disusun secara sebaik-baiknya, misalnya seimbang, simetris, antara unsur satu dengan unsur lainnya sangat erat hubungannya, dan sebagainya.

Puisi Indonesia semakin diminati oleh semua lapisan masyarakat Indonesia, tidak terbatas oleh anakanak, pelajar, dan mahasiswa saja. Hal ini merupakan bukti bahwa puisi dapat memberikan kenikmatan seni, selain itu memperkaya kehidupan batin masyarakat yang individualis dan industrialis. Salah satu permasalahan mendasar dalam proses pembelajaran sastra atau puisi adalah banyaknya teori-teori yang di kemukakan oleh para tokoh. Namun dalam kenyataannya, ketika teori-teori tersebut diajarkan di dalam kelas, siswa tidak seberapa faham sehingga gairah untuk mempelajarinya kuarang begitu antusias, dan tidak ada kemampuan untuk mempelajarinya. Sehingga untuk membuat respon siswa guru memberikan kebebasan untuk membuat puisi yang sesuai dengan teori-teori sastra atau puisi yang dipahami. Siswapun juga merasa antusias ketika disuruh menganalisis puisi.

Berdasarkan latar belakang di atas secara umum dapat di identifikasi bahwa kemampuan belajar siswa kelas V Surabaya khususnya pada pembelajaran menganalisis puisi, masih belum begitu paham atau rendah. Rendahnya kemampuan belajar siswa tentu berdampak pada hasil belajar mereka.

Berbekal dari hasil informasi-informasi yang ada, seorang guru harus melakukan inovasi dalam pembelajaran menganalisis puisi yaitu dengan menggunakan buku ajar yang berorientasi pada nilai-nilai islami. Dengan menggunakan buku ajar yang mengutamakan orientasi pada nilai-nilai islamiini menekankan pembelajaran yang didominasi oleh guru. Jadi guru berperan penting dan dominan dalam proses pembelajaran.

Berdasarkan buku ajar yang berorientasi pada nilai-nilai islami tersebut, menunjukkan bahwa pembelajaran langsung lebih menekankan peran guru daripada siswa. Dengan demikian, lebih cocok diterapkan 
pada siswa pada jenjang pendidikan yang kemampuan menganalisisnya masih relatif rendah.

Dari hasil pengamatan yang di peroleh maka peneliti menggambil sebuah langkah alternatif dengan menggembangkan buku ajar yang berorientasi pada nilainilai islami dengan model PBL agar proses pembelajaran lebih menarik dan mudah untuk diterapkan, maka analogianalogi dalam buku ajar ini dicontohkan langsung dan proses kegiatannya dilakukan dengan belajar kelompok. Menurut Sagala (2011:102) stimulasi belajar dapat diwujudkan melalui beberapa upaya seperti penggunaan media (buku ajar) atau alat-alat peraga, membuat variasi belajar pada siswa, memberikan stimulus belajar dalam bentuk lain sehingga tidak bosan. Kegiatan perancangan awal perangkat pembelajaran divalidasi oleh validator, diujicobakan terbatas, dan diujicobakan sesungguhnya dilapangan dilakukan dalam kegiatan penelitian dengan judul "pengembangan buku ajar berorientasi pada nilainilai islami dengan model PBL untuk meningkatkan kemampuan menganalisis puisi siswa kelas V'.

Dari pengungkapan di atas dapat dirumuskan suatu permasalahan sebagai berikut:

1. Bagaimanakah proses pengembangan dan kualitas buku ajar bahasa Indonesia berorientasi pada nilai-nilai islami untuk meningkatkan kemampuan menganalisis puisi siswa kelas $\mathrm{V}$ SD.

2. Secara umum tujuan penelitian ini adalah mengembangkan buku ajar berorientasi pada nilai-nilai islami, khususnya pada kelas $\mathrm{V}$ sekolah dasar.

3. Secara teoritis manfaat penelitian ini diharapkan mampu memberikan sumbangan dalam kegiatan pembelajaran Bahasa Indonesia dengan pengembangan buku ajar dengan nilai-nilai islami.

4. Produk yang dihasilkan dalam pengembangan ini adalah produk berupa buku ajar Bahasa Indonesia yang berorientasi pada nilai-nilai islami.

\section{METODE}

\section{Jenis penelitian}

Ditinjau dari aspek tujuan, penelitian ini merupakan penelitian pengembangan. Dalam penelitian ini dilakukan pengembangan buku ajar berorientasi pada nilai-nilai islami di kelas $\mathrm{V}$ sekolah dasar. Buku ajar hasil pengembangan ini akan diujicobakan dan hasil uji coba ini akan dianalisis secara deskriptif kualitatif untuk menjawab rumusan masalah sedangkan data kuantitatif untuk melihat nilai atau persentase data kualitas produk buku.

\section{Subyek penelitian}

Siswa kelas V Madrasah Ibtidaiyah PERSMIN Surabaya.

\section{Teknik Pengumpulan Data}

Data untuk menjawab rumusan masalah pertama yaitu tentang proses pengembangan buku ajar bahasa Indonesia ini diambil dengan teknik dokumentasi terhadap nilai-nilai islami serta KI dan KD. Data yang diolah berupa KI dan KD yang berasal dari standart isi kurikulum 2013.

Teknik pengumpulan data untuk menjawab masalah yang kedua yaitu tentang kualitas buku ajar dari penilaian validator dan dari segi penggunaannya menggunakan teknik validasi, observasi, angket, dan tes. Secara rinci dapat dijelaskan sebagai berikut:

a. Validasi

Teknik check list dan catat digunakan untuk memvalidasi pengembangan buku ajar bahasa Indonesia kelas $\mathrm{V}$ berorientasi pada nilai-nilai islami dengan model PBL untuk meningkatkan kemampuan menganalisis puisi mulai dari pendefinisian sampai pengembangan.

Validasi tahap pendefinisan dilakukan oeleh wali kelas V sekolah dasar. Aspek yang diamati berkaitan dengan analisis akar masalah, analisis siswa, analisis materi pembelajaran, analisis tujuan pembelajaran, dan analisis tujuan pembelajaran.

Validasi tahap perencanaan akan dilakukan oleh ahli materi/isi, bahasa, penyajian, dan kegrafikaan. Ahli materi dan bahasa Indonesia akan memvalidasi isi serta bahasa yang digunakan dalam keterkaitannya dengan EYD. Ahli penyajian akan memvalidasi penyampaian materi serta ahli kegrafikaan akan memvalidasi tata letak serta desain buku ajar yang dikembangkan.

Validasi terhadap pengembangan buku ajar berorientasi pada nilai-nilai islami akan dilakukan oleh ahli dalam bidang materi/isi, bahasa, penyajian, dan kegrafikaan serta wali murid. Mereka akan melakukan pengamatan terhadap buku ajar berorientasi pada nilai-nilai islami yang telah direvisi dan siap digunakan untuk meningkatkan kemampuan siswa kelas $\mathrm{V}$ SD. 


\section{b. Observasi}

Observasi dilakukan untuk mengamati proses pembelajaran dengan menggunakan buku ajar bahasa Indonesia kelas V SD berorientasi pada nilai-nilai islami dengan menggunakan model PBL. Pengamatan dilakukan terhadap aktivitas guru dan siswa selama proses pembelajaran.

c. Angket

Pengertian angket atau kuesioner menurut Arikunto (2006:151) adalah sejumlah pertanyaan tertulis yang digunakan untuk memperoleh informasi dari responden dalam arti laporan tentang pribadinya, atau hal-hal yang ia ketahui. Dalam penelitian ini angket digunakan untuk memperoleh data tentang tanggapan dan saran perbaikan dari tim validator (isi, penyajian, bahasa, dan kegrafikaan), guru dan siswa.

d. Tes

Pemberian tes meliputi pretest dan postest, sesuai dengan indikator dan tujuan pmbelajaran yang telah disusun oleh peneliti. Pretest dilakukan sebelum pembelajaran dimulai dengan tujuan untuk mengetahui pengetahuan awal siswa dan postest dilakukan setelah kegiatan pembelajaran.

\section{Teknik penganalisisan data}

Analisis data dalam penelitian ini dilakukan secara deskriptif dan statistik deskriptif. Analisis deskriptif berfungsi memberikan, memaparkan, atau menyajikan informasi. Sebagaimana pendapat Arikunto (2009:268), menyatakan bahwa penelitian yang menggunakan analisis deskriptif kualitatif adalah penelitian evaluasi yang bertujuan untuk menilai sejauh mana variabel yang diteliti telah sesuai dengan tolak ukur yang sudah ditentukan. Sedangkan dengan statistik deskriptik kumpulan data yang diperoleh akan tersaji dengan ringkas dan rapi serta dapat memberikan informasi inti dari kumpulan data yang ada (Walpole, 1993: 5).

Dalam penelitian ini, analisis yang dilakukan terhadap proses pengembangan buku ajar, kualitas buku ajar, dan pengimplementasikan buku ajar tersebut dalam proses mengajar. Analisis akan dijelaskan sebagai berikut:

a. Pada tahap pendefinisian dan perancangan. Analisis data untuk menjawab rumusan masalah pertama prses pengembangan buku ajar bahasa indonesia ini menggunakan teknik analisis deskriptif kualitatif b. Pada tahap pengembangan analisis data untuk menjawab rumusan masalah yang kedua kualitas produk ajar yang dikembangkan sesuai dengan nilai-nilai islami dilakukan melalui teknik analisis deskriptif kuantitatif dari hasil observasi terhadap aktivitas, respon guru dan siswa, serta hasil belajar siswa selam penggunaan draf II buku ajar.

\section{Prosedur Penelitian}

Model pengembangan yang digunakan dalam pengembangan buku ajar LKS berorientasi pada nilai-nilai islami dengan menggunakan model PBL adalah model 4-D dari Thiagarajan, dkk (1974:5) yang terdiri dari 4 tahapan pokok, yakni; 1. Define atau tahap pendefinisian, 2. Design atau tahap perancangan, 3. Development atau tahap pegembangan, 4. Disseminate atau tahap penyebaran. Setiap bagian prosedur pengembangan akan dijelaskan pada bagan berikut ini:

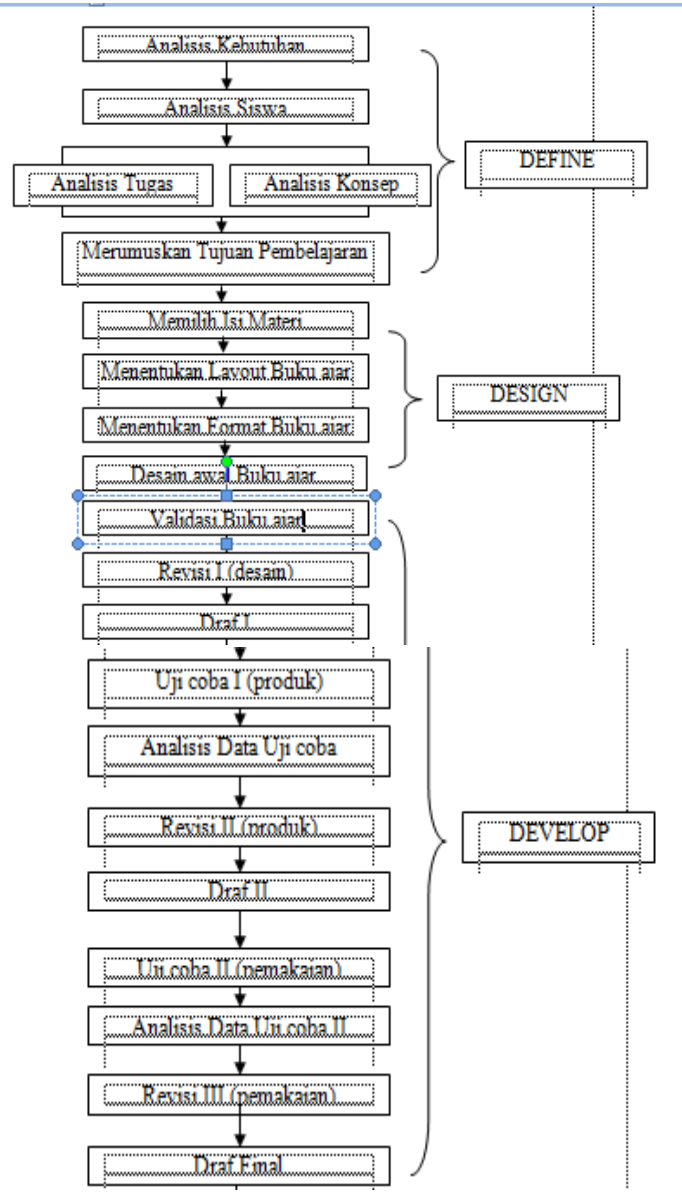

Bagan 1. Modifikasi Pengembangan buku ajar Adopsi Desain Four D Models (Tiagharajan, Semmel \& Semmel, 1974) 


\section{HASIL DAN PEMBAHASAN}

Setelah diketahui bahwa data berdistribusi normal dan homogen maka tahap selanjutnya dapat dilakukan uji t, karena syarat uji $\mathrm{t}$ ada datanya berdistribusi normal dan homogen (Sundayana, 2015:145). Untuk lebih terperinci hasil uji t dapat dilihat pada tabel berikut ini.

Berdasarkan uji $t$ pada data pretes tersebut menunjukkan bahwa t hitung sebesar -0,299 baik equal variance assumed ataupun pada equal variances not assumed. Pada taraf 5\% atau sebesar 2,064 pada t tabel, maka nilai t sebesar $-0,299<2,064$. Untuk mengetahui ada atau tidaknya pengaruh adalah dengan membandingkan $t$ hitung dengan $\mathrm{t}$ tabel. Syaratnya jika $\mathrm{t}$ hitung bernilai positif atau $\mathrm{t}$ hitung $>\mathrm{t}$ tabel maka ada pengaruh. Sebaliknya, jika $\mathrm{t}$ hitung bernilai negatif atau $\mathrm{t}$ hitung $<\mathrm{t}$ tabel maka tidak ada pengaruh (Sundayana, 2015:146). Oleh karena itu, hasil t hitung pada data pretes tersebut baik kelas ekperimen ataupun kelas kontrol bernilai negatif dan hasil $\mathrm{t}$ sebesar $-0,299<\mathrm{t}$ tabel sebesar 2, 064 maka dapat dinyatakan bahwa data pretes tidak ada pengaruh.

Cara kedua untuk membaca hasil uji $\mathrm{t}$ tersebut adalah dengan cara melihat sig. 2 tailed. Data dikatakan ada pengaruh jika nilai sig. 2 tailed di bawah 0,05 . Sebaliknya jika nilai sig. 2 tailed di atas 0,05 maka dinyatakan tidak ada pengaruh. Melalui data tersebut di atas nilai sig. 2 tailed sebesar 0,766 >0,05. Maka dapat dinyatakan bahwa data pada pretes tidak ada pengaruh.

Berdasarkan uji $\mathrm{t}$ pada data postes tersebut menunjukkan bahwa $\mathrm{t}$ hitung sebesar 9,853 baik equal variance assumed ataupun pada equal variances not assumed. Pada taraf 5\% atau sebesar 2,063 pada t tabel, maka nilai t sebesar 9,853 > 2,063. Untuk mengetahui ada atau tidaknya pengaruh adalah dengan membandingkan $t$ hitung dengan $\mathrm{t}$ tabel. Syaratnya jika $\mathrm{t}$ hitung bernilai positif atau $\mathrm{t}$ hitung $>\mathrm{t}$ tabel maka ada pengaruh. Sebaliknya, jika $\mathrm{t}$ hitung bernilai negatif atau $\mathrm{t}$ hitung $<\mathrm{t}$ tabel maka tidak ada pengaruh. Berdasarkan syarat tersebut, maka hasil $\mathrm{t}$ hitung pada data postes tersebut baik kelas ekperimen ataupun kelas kontrol bernilai positif dan hasil $\mathrm{t}$ sebesar 9,853>t tabel sebesar 2,063 maka dapat dinyatakan bahwa data postes ada pengaruh.

Cara kedua untuk membaca hasil uji t tersebut adalah dengan cara melihat sig. 2 tailed. Data dikatakan ada pengaruh jika nilai sig. 2 tailed di bawah 0,05 . Sebaliknya jika nilai sig. 2 tailed di atas 0,05 maka dinyatakan tidak ada pengaruh. Melalui data tersebut di atas nilai sig. 2 tailed sebesar $0,000<0,05$. Maka dapat dinyatakan bahwa data pada postes ada pengaruh.

Berdasarkan tabel hasil angket keterbacaan siswa terhadap buku ajar berorientasi pada nilai-nilai islami dengan menggunakan model PBL tersebut menunjukkan bahwa pemerolehan skor rata-rata siswa yang menjawab "ya" terhadap semua pertanyaan berjumlah 20 siswa dari total 24 siswa. Persentase pemerolehan siswa yang menjawab "ya" mencapai $83 \%$ dengan kriteria sangat tinggi. Sedangkan siswa yang menjawab "tidak" terhadap semua pertanyaan rata-rata memperoleh 4 siswa dari total 24 siswa, persentasenya mencapai $17 \%$ dengan kriteria sangat rendah. Siswa yang menjawab "ya" mencapai 18 siswa terdapat dalam pertanyaan nomor 2. Apakah tampilan dan isi buku ajar berorientasi pada nilai-nilai islami dengan menggunakan model PBL yang kalian baca menarik? 19 siswa terdapat dalam pertanyaan nomor 4 . Apakah gambar atau ilustrasi yang ada di buku ajar berorientasi pada nilai-nilai islami dengan menggunakan model PBL mudah dipahami? 20 siswa terdapat dalam pertanyaan nomor 1 . apakah buku ajar berorientasi pada nilai-nilai islami dengan menggunakan model PBL yang kalian baca menarik? dan 5. Apakah isi materi yang ada dalam buku ajar berorientasi pada nilai-nilai islami dengan menggunakan model PBL mudah dipahami? 23 siswa terdapat dalam pertanyaan nomor 3. Apakah pertanyaan yang ada di buku ajar berorientasi pada nilai-nilai islami dengan menggunakan model PBL menyenangkan untuk dijawab? Jadi dapat disimpulkan bahwa keterbacaan buku ajar berorientasi pada nilai-nilai islami dengan menggunakan model PBL termasuk kategori sangat tinggi.

Hasil penelitian yang dijabarkan pada Bab IV sebelumnya, akan didiskusikan dengan berdasarkan penemuan di lapangan. Berbagai penemuan tersebut dibahas dilapangan dengan teori yang dibuat para ahli sebelumnya. Untuk memahami dengan teori yang sesuai. Sehingga diharapakan adanya kesesuain antara fakta di diskusi hasil penelitian ini, akan dijelaskan pada proses pengembangan buku ajar berorientasi pada nila-nilai islami dengan menggunakan model PBL. Untuk lebih jelasnya akan diuraikan berikut ini:

a. Buku ajar berorientasi pada nilai-nilai islami dengan menggunakan model PBL dapat membantu siswa mengenali bermain.

b. Buku ajar berorientasi pada nilai-nilai islami dengan menggunakan model PBL dapat Membantu Siswa dalam Menyelesaikan Masalah berbagai benda - benda yang ada di Lingkungan Sekitar.

c. Buku ajar berorientasi pada nilai-nilai islami dengan menggunakan model dapat Menjadikan Siswa Lebih Aktif.

d. Keberhasilan proses pembelajaran dipengaruhi oleh kelengkapan sarana dan lingkungan sekolah. 


\section{PENUTUP}

\section{A. Simpulan}

Setelah dilakukan analisis data dan diskusi hasil penelitian maka dapat diketahui simpulan dari penelitian ini. Buku ajar berorientasi pada nilai-nilai islami dengan menggunakan model PBL layak digunakan dalam pembelajaran dan dapat digunakan untuk meningkatkan kegiatan belajar mengajar dalam menyelesakan masalah bermain dengan benda-benda lingkungan sekitar siswa. Hal tersebut dibuktikan dengan hasil validasi, kepraktisan, dan keefektifan berikut ini:

1. Hasil validasi Buku ajar berorientasi pada nilainilai islami dengan menggunakan model PBL adalah layak diterapkan dalam pembelajaran dengan sedikit revisi.

2. Kepraktisan Buku ajar berorientasi pada nilainilai islami dengan menggunakan model PBL dalam pembelajaran menunjukkan hasil yang yang sangat tinggi. Hal tersebut dibuktikan dengan hasil observasi aktivitas siswa, guru, dan hasil angket.

Buku ajar berorientasi pada nilai-nilai islami dengan menggunakan model PBL sangat efektif digunakan dalam pembelajaran. Buku ajar berorientasi pada nilai-nilai islami dengan menggunakan model PBL dapat digunakan untuk membelajarkan dan meningkatkan keterampilan penyelesaian masalah lingkungan sekitar siswa kelas $\mathrm{V}$ Sekolah Dasar. Hal tersebut dibuktikan dari hasil observasi kinerja siswa dalam menyelesaikan masalah bermain benda-benda dilingkungan sekitar yang memperoleh skor sangat tinggi.

\section{B. Saran}

Dari penelitian yang telah dilakukan dan hasilnya dapat diketahui tersebut, maka peneliti perlu memberikan saran, antara lain yaitu:

1. Untuk menciptakan Buku yang memiliki tingkat validitas yang tinggi, maka guru harus memperhatikan kebutuhan dan tujuan dibuatnya buku tersebut. Karena setiap buku memiliki kegunaan dan tujuan yang berbeda-beda, sesuai dengan fungsinya masing-masing. Sebelum buku dinilai kelayakanya perlu dilakukan analisis kurikulum, kebutuhan siswa, dan kondisi dan situasi sekolah. Hal tersebut dilakukan supaya tujuan diciptakannya buku dapat tercapai dengan maksimal.

2. Agar buku dapat digunakan dengan mudah oleh siswa, maka guru harus mengetahui karakteristik perkembangan dari siswa. Siswa pada tahap tertentu memiliki kemampuan tingkat berpikir yang berjenjang. Jangan sampai guru membuat buku yang materi atau soalnya terlalu sulit dijawab oleh siswa. Selain itu, untuk meningkatkan antusias siswa dalam mengejakan buku, maka buku harus didesain semenarik mungkin. Tujuannya adalah agar siswa bersemangat dan tidak cepat bosa mengerjakan setiap bagian dari buku tersebut.

3. Agar tujuan diciptakanya buku berhasil tepat sesuai tujuan pembelajaran, maka guru harus menguasai jalanya pembelajaran dengan baik. Guru harus kreatif dalam memanajemen kelas dan peka terhapap situasi dan kondisi pembelajaran. Karena dalam pembelajaran ada fase saatnya siswa bersemangat dalam mengerjakan, jenuh mengerjakan, dan lelah mengerjakan. Semua permasalahan tersebut membutuhkan penangan yang tepat sesuai dengan keadaanya.

\section{DAFTAR PUSTAKA}

Arikunto. Suharsimi. (2009). Dasar-Dasar Evaluasi Pendidikan. Jakarta: Rineka Cipta.

Badan Standart Nasional Pendidikan. (2006). Panduan Penyusunan Kurikulum 2013 Jenjang Pendidikan Dasar. Jakarta: Badan Standart Nasional Pendidikan.

Bogdan, R.C., Biklen, S.K. (1982). Qualitative Research for Education: An Introduction to Theory and Method. Boston: Alliyn and Bacon, Inc.

Chanzanagh, H. Ebadollahi and M. Akbarnejad. (2012). Work E THIC, Gender and Social Class in Ann Islamic Society: A Case Study in Iran.

Dahar, RW. (1998). Teori-Teori Belajar. Jakarta: Proyek Pengembangan Lembaga Pendidikan Tenaga Kependidikan.

Depdiknas. (2006). Kurikulum Standar Isi. Jakarta: Departemen Pendidikan Nasional.

Erozkan, Atilgan. (2013). The Effect of Communication Skills and Interpersonal Problem Solving Skills on Social Self-Efficacy. Spring Educational Consultancy and Research Center. Volume 2 Number $\quad 13$ pp. 737-745 https://eric.ed.gov/?q=problem+solving+skills\&i d=EJ1017303 Tanggal 19 November 2015.

Fogarty, Robin. (1991). The Mindful School: How to Integrete The Curricula. IRI/skylight Publishing, Inc: Pelatine, Illinois. 
Hudojo. (1988). Mengajar Belajar Bahasa. Jakarta: Proyek Pengembangan Lembaga Pendidikan Tenaga Kependidikan.

Indriyani, Umri Nur'aini. (2008). Bahasa Indonesia Sekolah Dasar. Surakarta: Depdiknas.

Kemendikbud. (2013). Modul Pedoman Pelatihan Implementasi Kurikulum 2013. Jakarta: Badan Pengembangan Sumber Daya Manusia Pendididkan dan Kebudayaan dan Penjamin mutu Pendidikan.

Krombab, Angela. (2008). Acquiring Knowledge about Biodiversity in a Auseum are Worksheets Effective?. Journal of biological Education 2008. Volume 42 Number 4 pp. 157-163 http://www.tandfonline.com/doi/pdf/10.1080/00 219266.2008.9656134 Tanggal 19 November 2015.

Marwati. (2011). Pengembangan Buku Ajar Apresiasi Prosa Berorientasi Pendidikan Berkarakter Siswa SMA Kelas X. Tesis Program Megister Pendidikan Bahasa dan Sastra Tidak Dipublikasikan.

Matson, Gill. (2012). The Impact of Specefic Langguage Impairment on Perfofmence in Science and Suggested Implication for Pedagogy. London: University College London.

Muslich, Mansur. (2010). Textbook Writing: Dasar-Dasar Pemahaman Penulisan dan Pemakaian Buku Teks. Jogjakarta: Ar-Ruzz Media.

Nurgiantoro, Burhan. (2011). Penilaian Pembelajaran Bahasa Berbasis Kompeteni Edisi 3.Yogyakarta: Anggota IKAPI. 